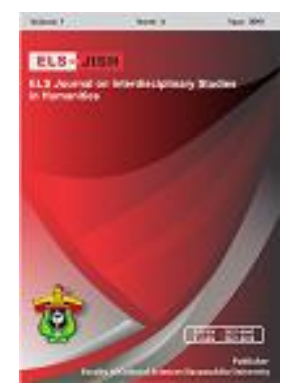

\title{
ELS-JISH
}

ELS Journal on Interdisciplinary Studies on Humanities

Volume 2 Issue 3, 2019

ISSN (print) : 2621-0843

ISSN (online) : 2621-0835

Homepage : http://journal.unhas.ac.id/index.php/jish

\section{Students' Perception of Listening Lesson at University of Riau}

\author{
Elvrin Septyanti ${ }^{1}$, Otang Kurniaman ${ }^{2}$ \\ 1 twetty.suni@gmail.com
}

\begin{abstract}
Listening is a skill in capturing the sounds of language by listening verbal language that receiving messages from other people's ideas, thoughts or feelings. This study aims to describe students' perceptions of listening lesson in the learning process. The method used is quantitative survey method with a total sample of 50 students of Indonesian language and literature education FKIP University of Riau who join listening lesson. This study uses a questionnaire technique that is distributed to students of the Indonesian Language and Literature Education Program at the University of Riau. Questionnaires consist of 17 statements made in the form of a checklist with a range of assessments from 1 to 5. Technical data analysis through stages (a) changes the value of the category into an assessment score and (b) analyzes the score, (c) determines the category. The results showed that the response of the students based on the highest experience was the desire to obtain complete teaching material by $70 \%$, the highest response of students to importance of media was if there were applications in listening lesson in accordance with current technology with a percentage of $80 \%$, and The highest student responses about the need for evaluation of listening lesson was the feedback of listening proficiency criteria set by the lecturer at $68 \%$. Then it can be concluded that students' perceptions of listening lesson are the desire for improvement in the media and applications in listening lesson that contain teaching material
\end{abstract}

Keywords: Student Perceptions, Listening Lesson, College

How to cite: Septiani, E., \& Kurniaman, O. (2019). Students' Perception of Listening Lesson at University of Riau. ELS Journal on Interdisciplinary Studies in Humanities, 2 (3), 368-377

\section{Introduction}

The most important media for communicating with others, namely through language, the process of giving and receiving information is interrelated. Language is also used to declare information, order, apply, threaten, bet, give advice, and so on. A good language determines the achievement of desired target information (Charlina et al., 2018). Teaching languages requires a long time depending on students in accordance with cognitive intelligence in accepting language (Kurniaman et al., 2018). Lack of language mastery will result in students being unable to express the received message influenced by verbal listening skills (Seau et al., 2018). Listening lesson in college is one of the compulsory subjects in the Indonesian Language and Literature Education program curriculum. Listening subjects are the basic courses of the four language skills that students must master,

\footnotetext{
${ }^{1,2}$ Universitas Riau, Indonesia 
especially for early-level students. The activities of the majority of teaching and learning process are through listening activities so that the listening ability also determines the success of learning. A listening subject has a course description to understand the theory of listening critically and skillfully listening critically. Regarding skilled and critical concepts in the course description, learning objectives are required to provide adequate listening skills for students. The skills referred to refer to exercises that can familiarize students in listening activities.

Tarigan (2008) defines listening as a process of listening to oral symbols with full attention, understanding, appreciation, and interpretation to obtain information, understand content or messages, and understand the meaning of communication that the speaker has conveyed through speech or spoken language. Therefore, listening is an activity that requires seriousness. and has the purpose of finding important information. Listening is an activity that undergoes a process. Listening is the skill of capturing the sounds of language spoken or read by others and transformed into a form of meaning to be continually evaluated, conclusions drawn and responded to (Suhendar and Supinah, 1992). Complementing the previous statement, Sutari et al (1998) suggested that listening has the meaning of listening or paying attention to what others say and the process of accepting other people's ideas, thoughts or feelings. Thus, listening also through several stages: the stage of hearing, the stage of understanding, the stage of interpreting, the stage of evaluating and the stage of responding. Furthermore, Tarigan (2008) gives opinions on listening stages that are used as references: listening periodically, listening superficially, half listening, listening to absorption, listening occasionally, listening sociatively, listening to periodic reactions, listening carefully, and listening actively.

Periodic listening is listening to the sounds of words but does not react to what is listened to. Listening intermittently is to do a recitation but briefly. In contrast to half listening, following the conversation with the intention to convey his own ideas to an opportunity. This is also related to extensive and intensive listening (Kurniaman \& Huda, 2018). There are seven factors in explaining differences in individual learners, namely beliefs, affective states, age, talent, learning style, motivation, and personality. As one of the factors in learning, learning style also needs to be considered. When educators know their students' learning styles, they can facilitate their students to learn better with the right teaching strategies (Ellis, 2005; Mulyadi et al., 2017). Extensive listening, a kind of listening activity on things that is more general and clearer to a utterance, is not necessary under the direct guidance of a teacher (Tarigan, 2008). This listening activity also provides an opportunity for students to hear and listen to the points of vocabulary and structures that are still unfamiliar and or that have just been heard by students. The forms of activity, namely social listening, secondary listening, aesthetic listening, and passive listening (Nurani et al., 2018).

Intensive listening is directed at an activity that is more supervised, controlled by one particular thing. This activity, for example, is directed as part of a language teaching program and is directed at understanding and understanding in general. The ones that include extensive listening are listening critically, listening to the conservative, listening to the creative, listening to explorations, listening to the interrogative, and selective listening (Tarigan, 2008). The listening learning process can be carried out through several techniques that can be applied, for example: reciting speech, chime chain, keyword identification, paraphrasing, summarizing, identifying topic sentences, answering questions, and finishing stories. In practice, listening subjects still have constraints on both facilities and infrastructure and even the media used. Constraints arise because of reluctance to get involved, fear of change, desire to avoid questions, satisfied with external appearance, premature considerations, and semantic confusion.

This is a challenge for lecturers to achieve the most effective learning goals. In addition, listening textbooks are not sufficient enough, moreover there are no prepared 
materials by experts so that they can be used by universities in listening lesson. During this time, the feed ingredients are only facilitated by videos on youtube, infocus and speaker. This requires listening lesson to be innovative in every implementation. In its implementation, a students perceptions related to the learning process applied by lecturers are needed. So, there are evaluations that serve as guidelines for lecturers to provide innovation both in terms of teaching materials, teaching media so that the learning objectives that have been designed are well implemented. The purpose of this study is to illustrate the perceptions of students in listening lesson in college.

\section{Method}

This research is a quantitative research with survey methods. The research method is descriptive quantitative research. Descriptive quantitative research is a research method that shows the phenomena that exist and provides an overview by using the numbers as a reinforcement of the results of the study which will be described in words to provide an overview of the numbers that appear in the study (Sugiyono, 2015). The number of students who became the study sample were 50 students from the Indonesian Language and Literature Education Study Program FKIP Riau University. The variable of this study is single, namely the perception of Indonesian Language and Literature Education study students towards listening lesson.

Data collection techniques in this study were questionnaires. Questionnaires are compiled and refer to the principles of the Likert scale to measure attitudes, opinions, and or perceptions of people. Questionnaires are arranged in the form of a checklist with a range of assessments 1 to 5. Questionnaires consist of positive and negative statements. The instruments given to students provide 5 alternative answers: strongly agree (ss) $=5$, agree $(s)=4$, quite agree $(\mathrm{cs})=3$, disagree $(\mathrm{ts})=2$, strongly disagree $(\mathrm{sts})=1$. But different for negative statements. (ss) $=1$, agree $(\mathrm{s})=2$, quite agree $(\mathrm{cs})=3$, disagree (ts) $=4$, strongly disagree (sts) $=5$. Questionnaires are aimed at students to improve the quality of learning according to the suggestions and criticisms expected and the opinions of lecturers who teach the Listening Lesson. The data analysis technique consists of 3 stages: (a) changing the value of the category into an assessment score and (b) analyzing the score, (c) determining the category. The criteria are defined as perceptions of improvement in listening to subject learning.

Table 1. Perception Category

\begin{tabular}{cc}
\hline Rating level & category \\
\hline $0 \%-20 \%$ & very low \\
$20,1-40 \%$ & Less \\
$40,1 \%-60 \%$ & Good enough \\
$60,1 \%-80 \%$ & Good \\
$80,1-100 \%$ & Very good \\
\hline
\end{tabular}

\section{Findings}

This research was conducted to students of the Indonesian Language and Literature Education Study Program, FKIP, Riau University with a sample of 50 students taking listening lesson, so that it became a reference as a perception that students wanted to learn. By giving a questionnaire in taking perception data with indicators (1) experience response indicators for listening lesson, (2) indicators of student responses to the importance media of listening lesson, and (3) response indicators of student needs for evaluation of listening lesson. The student's first response will be seen in table 2 .

Table 2. Respondent's Response to Listening Learning 
Elvrin Septyanti. 2(3): 368-377

\begin{tabular}{|c|c|c|c|c|c|c|c|c|c|c|c|}
\hline \multirow[t]{2}{*}{ Statement } & \multirow[t]{2}{*}{ Description } & \multicolumn{2}{|c|}{1} & \multicolumn{2}{|c|}{2} & \multicolumn{2}{|c|}{3} & \multicolumn{2}{|c|}{4} & \multicolumn{2}{|c|}{5} \\
\hline & & $\mathbf{F}$ & $\%$ & $\mathbf{F}$ & $\%$ & $\mathbf{F}$ & $\%$ & $\mathbf{F}$ & $\%$ & $\mathbf{F}$ & $\%$ \\
\hline P1 & $\begin{array}{l}\text { I want to get complete } \\
\text { listening } \\
\text { during the listening } \\
\text { process }\end{array}$ & 0 & 0 & 0 & 0 & 9 & 18 & 6 & 12 & 35 & 70 \\
\hline P2 & $\begin{array}{l}\text { I got a textbook in the } \\
\text { form of complete } \\
\text { teaching material }\end{array}$ & 2 & 4 & 3 & 6 & 12 & 24 & 13 & 26 & 20 & 40 \\
\hline P3 & $\begin{array}{l}\text { I got teaching material } \\
\text { listening aside from } \\
\text { the book, like the } \\
\text { ingredients from the } \\
\text { video }\end{array}$ & 0 & 0 & 4 & 8 & 7 & 14 & 12 & 24 & 27 & 54 \\
\hline P4 & $\begin{array}{l}\text { I only got teaching } \\
\text { material only through } \\
\text { power point media }\end{array}$ & 11 & 22 & 6 & 12 & 9 & 18 & 10 & 20 & 14 & 28 \\
\hline
\end{tabular}

Information: $\mathrm{P}$ = statement, 1 = strongly disagree, 2 = disagree, 3 = quite agree, 4 = agree, 5 = strongly agree

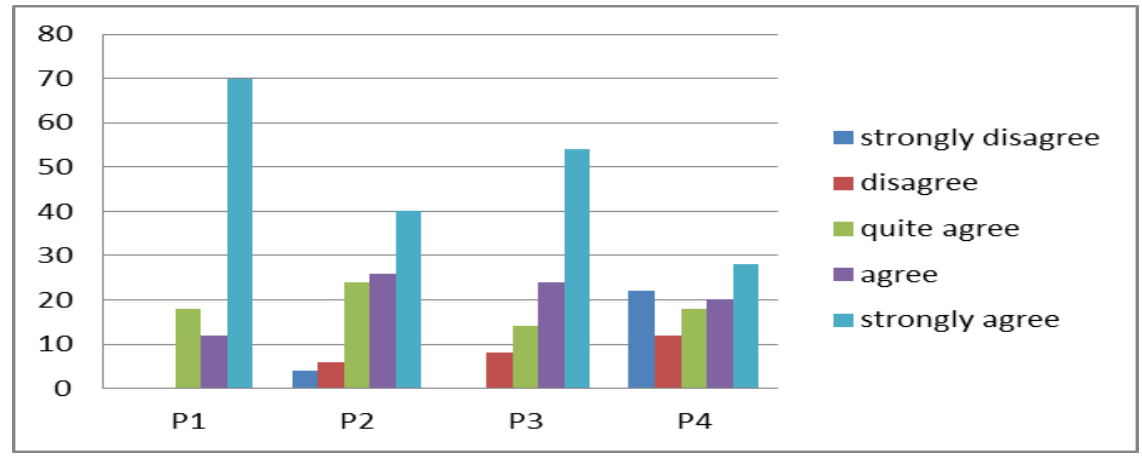

Figure 1. Response of Respondents' Experience Towards Listening Lesson

The response to the desire of students to get complete listening lesson has good criteria. This is seen based on $70 \%$ of students filling out the questionnaires. During the listening lesson, students assessed that they did not get textbooks with complete teaching material. This is seen based on $40 \%$ of students who gave scores on number 2 questionnaire statements. In addition, as many as $54 \%$ of students rated quite well the teaching materials given by lecturers. In listening to the learning not only given by books but also ingredients from the video. Twenty-eight percent of other students agreed that students only get teaching material only through power point media. Based on the shortcomings in the learning process, students need adequate listening lesson. It mean, This need must be supported by the design of learning, textbooks, innovation of learning media. Furthermore, the response to the importance of listening lesson media can be seen in the following table.

Table 3. Student Responses to The Importance of Listening Learning Media 
ISSN: (E) 2621-0835, (P) 2621-0843

\begin{tabular}{|c|c|c|c|c|c|c|c|c|c|c|c|}
\hline \multirow[t]{2}{*}{ Statement } & \multirow[t]{2}{*}{ Description } & \multicolumn{2}{|c|}{1} & \multicolumn{2}{|c|}{2} & \multicolumn{2}{|c|}{3} & \multicolumn{2}{|c|}{4} & \multicolumn{2}{|c|}{5} \\
\hline & & $\mathbf{F}$ & $\%$ & $\mathbf{F}$ & $\%$ & $\mathbf{F}$ & $\%$ & $\mathbf{F}$ & $\%$ & $\mathbf{F}$ & $\%$ \\
\hline P5 & $\begin{array}{l}\text { Audio visual } \\
\text { learning media is } \\
\text { very important in } \\
\text { listening lesson }\end{array}$ & 0 & 0 & 0 & 0 & 6 & 12 & 11 & 22 & 33 & 66 \\
\hline P6 & $\begin{array}{l}\text { An interactive CD } \\
\text { is needed for } \\
\text { exercises inside } \\
\text { and outside the } \\
\text { classroom }\end{array}$ & 2 & 4 & 3 & 6 & 12 & 24 & 13 & 26 & 20 & 40 \\
\hline P7 & $\begin{array}{l}\text { Interactive videos } \\
\text { make students } \\
\text { interested in } \\
\text { learning }\end{array}$ & 2 & 4 & 0 & 0 & 8 & 16 & 12 & 24 & 28 & 56 \\
\hline P8 & $\begin{array}{l}\text { Students are } \\
\text { interested if there } \\
\text { is an application } \\
\text { that summarizes } \\
\text { the material and } \\
\text { ingredients that } \\
\text { can be opened } \\
\text { anywhere }\end{array}$ & 0 & 0 & 0 & 0 & 1 & 2 & 9 & 18 & 40 & 80 \\
\hline P9 & $\begin{array}{l}\text { The courses are } \\
\text { interesting } \\
\text { listening if there } \\
\text { are listening } \\
\text { exercises through } \\
\text { audio at each } \\
\text { meeting }\end{array}$ & 1 & 2 & 3 & 6 & 7 & 14 & 12 & 24 & 27 & 54 \\
\hline P10 & $\begin{array}{l}\text { The use of } \\
\text { learning videos is } \\
\text { an effort to } \\
\text { increase power to } \\
\text { see }\end{array}$ & 0 & 0 & 0 & 0 & 6 & 12 & 12 & 24 & 32 & 64 \\
\hline P12 & $\begin{array}{l}\text { Students want an } \\
\text { interactive video } \\
\text { that explains the } \\
\text { full material }\end{array}$ & 0 & 0 & 0 & 0 & 5 & 10 & 10 & 20 & 35 & 70 \\
\hline
\end{tabular}

Information: $\mathrm{P}$ = statement, 1 = strongly disagree, 2 = disagree, $3=$ quite agree, $4=$ agree, 5 $=$ strongly agree 


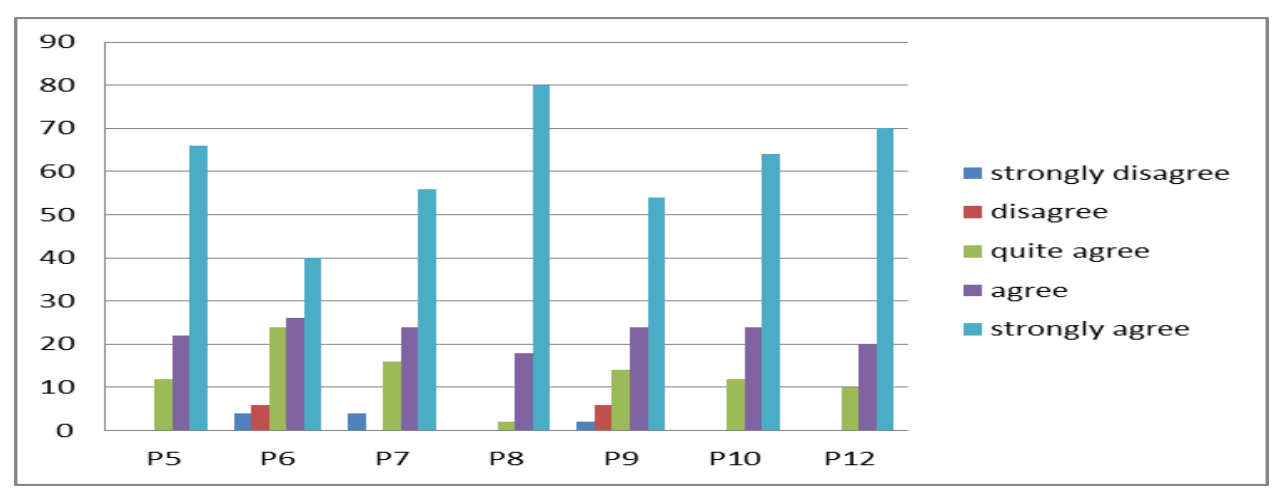

Figure 2. Student Response on The Importance of Listening Learning Media

The percentage of student responses to the importance of listening media is very good. This criterion is in accordance with the specified criteria, namely 80.1 to 100 shows a very good response to the wishes of students, especially the desire of students to get learning media through certain applications that can summarize the material and ingredients of the treat. Based on figure 2. There are $80 \%$ of students from 50 respondents who agree to statement number 8 . This is comply with technological developments in era 4.0 . In the lecture process, college is required to harmonize the learning process with technology. In this case, the application summarizes the material and material used for the learning process. Then, this response was strengthened by $70 \%$ of students also want to at listening courses provide interactive learning videos that summarize the teaching material in full. This shows that audio visual learning media is very important in listening lesson. Students give a good response with a percentage of $66 \%$ in the assessment statement in number P5. Learning videos are also a part of increasing students' listening power. This was also approved by more than $50 \%$ of students. Based on tabulated responses, $64 \%$ of students responded with good respons to P10. Students assume, lectures will be more interesting if facilitated with learning videos during the lecture process. This got a very good response. This is shown based on percentage with 56. In addition, 54\% think it is good enough if the learning video is trained to students at each meeting listening. However, the related materials designed in the CD/ DVD lacked a good response from the students. That is, they don't really need a CD in the form of feed ingredients. This is indicated by $40 \%$ of students with less criteria in listening media learning needs. CD are considered inefficient in the learning process. Learning preparation is also not as effective as learning media in the form of applications that are considered more practical and always exist in laptop or notebook files.

Table 4. Responding to Student Needs For Evaluation of Listening Learning

\begin{tabular}{|c|c|c|c|c|c|c|c|c|c|c|c|}
\hline \multirow[t]{2}{*}{ Statement } & \multirow[t]{2}{*}{ Description } & \multicolumn{2}{|c|}{1} & \multicolumn{2}{|c|}{2} & \multicolumn{2}{|c|}{3} & \multicolumn{2}{|c|}{4} & \multicolumn{2}{|c|}{5} \\
\hline & & $\mathrm{F}$ & $\%$ & $\mathrm{~F}$ & $\%$ & $\mathrm{~F}$ & $\%$ & $\mathrm{~F}$ & $\%$ & $\mathrm{~F}$ & $\%$ \\
\hline P11 & 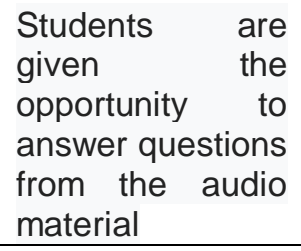 & 0 & 0 & 0 & 0 & 8 & 16 & 15 & 30 & 27 & 54 \\
\hline P13 & $\begin{array}{l}\text { Students always } \\
\text { get written } \\
\text { examinations in } \\
\text { either UTS or } \\
\text { UAS }\end{array}$ & 3 & 6 & 1 & 2 & 10 & 20 & 10 & 20 & 26 & 52 \\
\hline
\end{tabular}


ISSN: (E) 2621-0835, (P) 2621-0843

\begin{tabular}{|c|c|c|c|c|c|c|c|c|c|c|c|}
\hline P14 & $\begin{array}{l}\text { Students want } \\
\text { to be facilitated } \\
\text { video in } \\
\text { summative } \\
\text { tests }\end{array}$ & 1 & 2 & 0 & 0 & 9 & 18 & 18 & 36 & 22 & 44 \\
\hline P15 & $\begin{array}{l}\text { Students want } \\
\text { to be facilitated } \\
\text { videos in } \\
\text { formative tests }\end{array}$ & 0 & 0 & 0 & 0 & 11 & 22 & 20 & 40 & 19 & 38 \\
\hline P16 & $\begin{array}{l}\text { Students are } \\
\text { given feedback } \\
\text { on listening } \\
\text { proficiency } \\
\text { criteria by } \\
\text { lecturers }\end{array}$ & 1 & 2 & 0 & 0 & 6 & 12 & 9 & 18 & 34 & 68 \\
\hline P17 & $\begin{array}{l}\text { Listening } \\
\text { teaching material } \\
\text { that is carried out } \\
\text { is in accordance } \\
\text { with the expected } \\
\text { learning } \\
\text { objectives }\end{array}$ & 0 & 0 & 0 & 0 & 37 & 74 & 8 & 16 & 5 & 10 \\
\hline
\end{tabular}

Information: $\mathrm{P}$ = statement, 1 = strongly disagree, 2 = disagree, $3=$ quite agree, 4 = agree, 5 = strongly agree

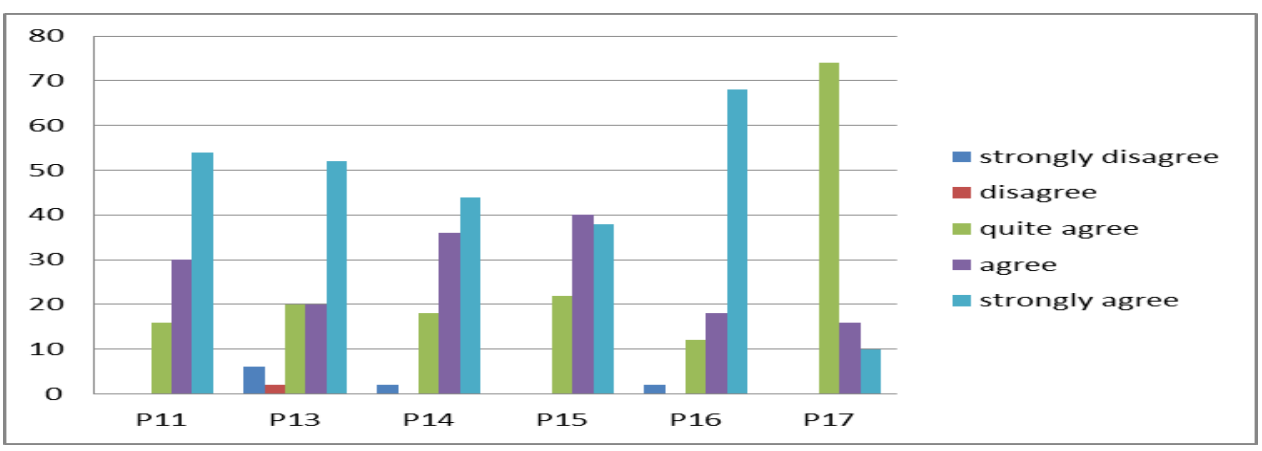

Figure 3. Responding to Student Needs For Evaluation of Listening Lesson

In the third indicator, related to the response of students' needs to the evaluation of listening lesson, there were 6 statements representing the percentage of student assessment criteria. As many as $68 \%$ of students gave a good assessment of their desire to be given feedback on the criteria for each student. They assume that listening skills of students can be measured by certain criteria. Not only includes the field of knowledge but also the skills of students in terms of listening activities. This can be obtained through intensive training in listening to audio materials. The percentage shows $54 \%$ of students stated that this was good enough to apply. However, overall for the evaluation of listening lesson to students did not expect the assessment to only come from listening to the video. That is, their response is less interested if the assessment is only sourced from the ingredients only without involving knowledge tests. This is indicated by $38 \%$ of students who only approve if the formative test only comes from video. Evaluation of listening learning must include listening knowledge and skills. During the lecture process, students assume that the success of listening to the learning objectives is still sufficient. This criterion is seen based on $74 \%$ of students who 
respond to listening lesson quite agree. Only $10 \%$ of students considered that learning objectives of listening were in accordance with what was expected. That is, the success of learning objectives is still in the less category.

\section{Discussion}

Listening lesson is an activity that really requires concentration in learning. The role of the teacher in listening lesson activities is influenced by internal and external. Internal factors that influence the understanding of the role of the teacher are made by the teacher themselves and can be classified into two categories: teacher beliefs about important roles and teacher expectations for their roles, and external factors including views and expectations of the teacher's role, which arise in other stakeholders, such as students, parents, colleagues, school leaders, and the community. Both types of factors are also an important part of the teacher's professional identity (Makovec, 2018). The desire of students is to provide learning by using learning media that are able to facilitate listening lesson not only by using power point but also provide direct practice to optimize language skills specifically in listening skills (Kurniaman \& Noviana, 2016). This also, audio-visual learning media is very important in listening lesson because it is one part of increasing students' listening power, so that it will influence other speaking skills and others (Kafryawan et al., 2018).

A good listener who has extensive knowledge and experience. If the listener has extensive knowledge and experience, he can do well listening activities. In addition, good listeners are listeners who can carry out intensive listening activities. Such listeners will always get the speaker's message appropriately (Serenande, 2011). Listeners must understand about linguistic and nonlinguitic forms in oral communication, so that they can absorb the meaning of the communication and be able to capture the message conveyed by the speaker (Iskandar, 2019). Therefore in listening activities there is an element of deliberation, attention and understanding, which is the main element in each listening event. The assessment is always present in the event of listening, even exceeding the element of attention (Mulyani, 2014).

Student difficulties in listening, this difficulty is not about external and internal characteristics that might affect listening comprehension of the text. Instead, this is a realtime processing problem, directly related to cognitive procedures that occur at various stages of understanding. Students have described these difficulties in their own words when they think of certain situations when they listen (Meng, 2000). For this reason, we need a media that is able to provide an overview facilitating student listening lesson. Language skills are strongly influenced by cognitive and concentration in carrying out learning so that if there is an eating disorder it will affect the delivery of the message to the listener (Kurniaman \& Sismulyasih Sb, 2019). The teacher can harmonize the assessment in listening skills according to context, such findings remind us that all language teaching takes place in certain social, cultural and institutional contexts and conflicting priorities and the inevitable contradictions that exist in this context become a problem (Johnson, 2018). The conceptualization of listening lesson is a factor that can influence the thoughts and actions of language teachers during teaching in accordance with their experiences during their schooling and direct experience in learning practices when they study for students' perceptions of being built when they attend lectures with lecturers (Jackson \& Cho, 2018) .

\section{Conclusion}

The conclusions in this study are the need for innovation in listening lesson so that learning objectives accordance with the description of courses designed for students. The listening lesson also not only provide students with adequate knowledge but also provide adequate power skills as well. Of course, an adequate learning process is also very necessary. Learning design, textbooks, learning media are important in the components of 
listening lesson. In this case, the learning component needs to work well together so that the listening process and learning outcomes corresponding to expected learning objectives.

\section{Acknowledgments}

Thank you to the chairman of the LPPM who gave the research grants Dosen Muda, not forgetting also to the members of the research who had helped in this research.

\section{References}

Charlina, C., Sinaga, M., Septyanti, E., \& Kurniaman, O., (2018). Teacher Speech Act in Learning Process at Special School in Pekanbaru. Advanced Science Letters, 24(10), 7120-7123.

Ellis, R. (2005). The Study of Second Language Acquisition. Shanghai: Shanghai Foreign Education Press.

Iskandar, D. (2019). Keterampilan Menyimak. [online] 25 Juli 2019. http://file.upi.edu/Direktori/FPBS/JUR. PEND. BHS. DAN SASTRA INDONESIA/19 6606291991031-DENNY ISKANDAR/MATERI MENYIMAK SMP.pdf.

Johnson, K. E. (2018). Studying language teacher cognition: Understanding and enacting theoretically consistent instructional practices. Language Teaching Research, 22(3), 259 -263. https://doi.org/10.1177/1362168818772197.

Jackson, D. O., \& Cho, M. (2018). Language teacher noticing: A socio-cognitive window on classroom realities. Language Teaching Research, 22(1), $29-46$. DOI: 10.1177/1362168816663754.

Kurniaman, O., Zufriady, Z., Mulyani, E. A., \& SB Simulyasih, N. (2018). Reading Comprehension Skill Using Graphic Organizer for Elementary School Students. Journal of Teaching and Learning in Elementary Education (JTLEE), 1(2), 75-80.

Kurniaman, O., \& Huda, M. N. (2018). Penerapan Strategi Bercerita untuk Meningkatkan Keterampilan Menyimak Siswa Kelas III SD Muhamadiyah 6 Pekanbaru. Primary: Jurnal Pendidikan Guru Sekolah Dasar, 7(2), 249-255.

Kurniaman, O., \& SB. Sismulyasih, N. (2019). The Influence of The Big Book Media Has The Character of Conservation in Early Reading. ELS Journal on Interdisciplinary Studies in Humanities, 2 (1), 141-147.

Kurniaman, O., \& Noviana, E. (2016). Metode Membaca SAS (Struktural Analitik Sintetik) dalam Meningkatkan Keterampilan Membaca Permulaan di Kelas I SDN 79 Pekanbaru. Primary: Jurnal Pendidikan Guru Sekolah Dasar, 5(2), 149-157.

Kafryawan, W; et al. (2018). The Influence of Intelligence on Students' Speaking Skills. ELS Journal on Interdisciplinary Studies in Humanities, 1 (2), 145-152.

Mulyadi, D., Rukmini, D., \& Yuliasri, I. (2017). The Analysis of Students' Listening Proficiency Viewed from Their Different Learning Styles after Getting the Strategy Instructions. Theory and Practice in Language Studies, 7(12), pp. 1200-1209. DOI: http://dx.doi.org/10.17507/tpls.0712.06.

Makovec, D. (2018). The Teacher's Role And Professional Development. (IJCRSEE) International Journal of Cognitive Research in Science, Engineering and Education, 6(2), 33-46. doi:10.5937/ijcrsee1802033M.

Meng, C. G. C. (2000). A Cognitive Perspective on Language Learners' Listening Comprehension Problems. System, 28(1), 55-75. http://dx.doi.org/10.1016/S0346251X(99)00060-3. 
Mulyani, T. (2014). Keterampilan Menyimak. [online] 25 Juli 2019. http://mtrimulyani.blogspot.com/2014/12/keterampilan-menyimak.html.

Nurani, R. Z., Nugraha, F., \& Sidik, G. S. (2018). Penggunaan Media Audio Visual dalam Pembelajaran Menyimak Dongeng di Era Digital. EduHumaniora: Jurnal Pendidikan Dasar, 10(2), 78-84.

Suhendar, \& Supinah, P. (1992). Bahasa Indonesia (Keteramilan Membaca dan Menulis). Bandung: CV Pioner Jaya.

Sutari, I. KY., et al. (1998). Menyimak. Jakarta: Depdikbud.

Seau, L. S., Azman, H., \& Noor, N. M. (2018). A Responsive Pedagogical Initiative for Multimodal Oral Presentation Skills: An Action Research Study. 3L: The Southeast Asian Journal of English Language Studies, 24(2), 29 - 42. http://doi.org/10.17576/3L-2018-2402-03.

Sugiyono. (2015). Metode Penilitian kuantitatif Kualitatif dan R\&D. Bandung: Alfabeta.

Serenande, S. (2011). Keterampilan Menyimak. [online] 25 Juli 2019. http://aristhaserenade.blogspot.com/p/keterampilan-menyimak.html.

Tarigan, H. G. (2008). Menyimak Sebagai Suatu Keterampilan Berbahasa. Bandung: Angkasa. 